\title{
Kidas Model, Cash Flow, and Size Case of Palestine
}

\author{
Tamer Bahjat Sabri ${ }^{1}$ \\ 1 Associate Professor, Department of Computerized Financing and Banking, The College of Business and \\ Economics, Palestine Technical University, Kadoorie, Tulkarm, Palestine \\ Correspondence: Tamer Bahjat Sabri, Associate Professor, Department of Computerized Financing and Banking, \\ The College of Business and Economics, Palestine Technical University, Kadoorie, Tulkarm, Palestine. E-mail: \\ T.sabri@ptuk.edu.ps
}

Received: January 16, 2021

Accepted: February 3, 2021

Online Published: March 11, 2021

doi:10.5539/ijbm.v16n4p48

URL: https://doi.org/10.5539/ijbm.v16n4p48

\begin{abstract}
This paper examines the nature of interaction between Kida's model, the cash flows (operating, investing, financing) and the size. It covers the period between 2013 and 2014 based on annual financial statement of Palestinian listed companies in Palestine Stock Exchange. In order to test the hypotheses of the study, the researcher used independent samples T-test. The results show that we accept all null hypotheses, so Kida's model does not distinguish between high and low cash flow (operating, investing, financing) and the size. Other results show that the model is unable sometimes to predict the failure of companies.
\end{abstract}

Keywords: Kida's model, independent samples t-test, Palestinian listed companies, operating cash flow, investing cash flow

\section{Introduction}

The failure of companies is one of the hottest topics that guide a lot of writers and researchers to study it, because it may result in negative effects on the national economy, and society as a whole (management, current and prospective investors, banks, creditor, auditors, and government agencies).

And because of its serious impact on the company level and the national economy and even on a global scale, since the failure and the bankruptcy of a number of large international companies like what happen in September 152008 when Lehman Brothers filed for bankruptcy (Buckley, 2011), which in turn lead to a financial crisis. There are several Palestinian listed companies that have made losses during the period of the study. so there are fears that some of them fall in the financial problems affecting the Palestinian economy

A company's life cycle is characterized by a number of different stages in which it takes different forms and different directions and each stage is characterized by a range of different objectives

In general, we can say that the financial failure has several aspects, including economic failure which means that the firm's revenue does not cover its total costs. Business failure includes any firm that has terminated operation with a resultant loss to creditors. (Brigham \& Gapenski, 1994).

Recent decades have shown how important it is to take advantage of the financial analysis. Using financial ratios is not in the assessment of the previous activity of the enterprises, but also in predicting the extent of the financial efficiency for its future activities and to provide a means for early warning for the firms. (Shaker, et al., 2008). So Many researchers began to find a way by which to predict failure before it occurs, and emerged as a result. Many studies using financial ratios as tools for some models such as Altman and Kida in order to predict the failure before it happens .

After the crisis, it important to predict and know the relation between the financial ratio in the models and the cash flows. The cash flow analysis gains great importance for businesses, because this type of analysis has an important role in the planning and the decision-making process of those facilities. The traditional financial statements including (income and financial position) are prepared in accordance with accrual basis. The financial statements presented by these lists do not reveal, in fact the truth of cash flows for the activities of operating, investing and financing company. The study aims to achieve connectivity between Kida model and the items in the statement of cash flows. Where Kida model relying on the income statement and balance sheet to calculate the ratios. 
The study attempts to answer the following questions: Is Kida's model able to predict or to distinguish between the failed and non-failed Palestinian listed companies? Are Palestinian listed companies that have high (operating, investing, financing) cash flows different in Z-score from the companies that have low cash flows? Are Palestinian listed companies that have high assets are different in Z-score from companies that low have assets? Are Palestinian listed companies that have high equity different in Z-score from the companies that low have equity?

The paper includes four sections: The first section contains Literature review that begin with the (Mears, 1966) and end with a study (Shaheen \& Mater, 2011). The second section is the methodology and contains the study model, study variables, data and hypotheses of the study. and the third section contains the results of the study and hypothesis testing, and the fourth section conclusioncontains results, study contribution and future prospects.

\section{Literature Review}

(Mears, 1966) explained the importance of financial ratios to predict the failure of the enterprises. And (Beaver, 1966) explained that financial ratios must be used, but must be taken into account that not all are able to predict in the same degree. (Wilcox 1970), examines the theory of financial ratios to predict the failure of the companies in an attempt to improve the model that was created by William H. Beaver. And (Edmister, 1972) used a number of methods of analysing financial ratios to predict small business failure.

Other articles stressed the importance of models. (Collins,1972) compares the effectiveness of the distinctive analysis and linear methods to predict the likelihood of bankruptcy. The results reveal that both the bankruptcy forecasting methods offer good predictive results. As well as (Collins, 1980) examine both Altman and the Meyer and Pifer Methods of bankruptcy prediction provide good predictive results. (Shirata, 1998) the researcher proposed in this study a universal model which is independent of industry and size. (Shirata20110 analysed the sentences in financial reports in Japan and extracted key phrases/descriptions to predict bankruptcy. (Bărbuță-Mişu \& Codreanu 2014), used two well-known models: Conan \& Holder, and Altman. (Ugurlu and Aksoy2006) show the accuracy of differentiation logarithmic model, which is used in emerging markets when companies are facing great uncertainty and turmoil.

Studies have been applied in many countries (Keener, 2013) has been applied in the United States companies from the retail industry. The results show that small retail firms that have a small number of employees are more likely to fail. Also, companies that have the lowest percentage of cash to current liabilities, lower margins and cash flows, and high debt to capital ratio are more likely to bankruptcy. (Doukas, 1986) applied in Canada. As for the Middle East (Rmo \& Alwatar, 2010) aim to find a liable way to predict the failure by applying the model of Altman on a number of Iraqi companies. (Al-hmadani \& Al-qtan, 2013) applied their study in Iraq. (Abu Orabi, 2014) used Altman and Sherrod models. The results showed that there was not a great ability for the models to predict the financial failure of Jordanian shareholding companies. (Alawi \& Graibh, 2008) applied their study in Jordan. The study aimed to examine the ability of financial ratios to predict defaults on Jordanian companies. (Alkhatib \& Al Bzour, 2011) applied their study in Jordan but the study used Altman and Kida models. There was not a great ability for the models to predict the financial failure. This is because the listed companies probably do not use models in financial analysis and credit.

But (Al-Sulaiti \& Almwajeh, 2007) used other models. The statistical conclusion of the study shows that both discriminant Analysis and Logistic Regression models are able to predict organizations' financial status and whether they are going to succeed or fail. (Almansour, 2015) Predicted future financial situations of individual corporate entities in Jordan. At the local level there is a study for (Shaheen \& Mater ,2011) The study aims to reach the best combination of financial ratios that can be used to predict defaults on banking enterprises in Palestine and to distinguish between distressed and non-distressed.

\section{The methodology}

\subsection{The Model}

The selected model Kida's $Z$ score Model, which is one of the important models quantity for predicting failure. Kida's $\mathrm{Z}$ score Model relied on five financial ratios which include all aspects of operational performance in companies.

The high likelihood of failure by this model when the value shows companies that have a Z-score of $>0.38$ are considered as a good sign for being successful. Compared to those which have a Z-score of $<0.38$ had potential serious problems and may not be able to continue. This model has proven predictive ability of incidents of failure of $90 \%$ a year before it occurs early. All parties and actors regulators to intervene to take appropriate corrective action in a timely manner (Alkhatib \& Al Bzour, 2011). 
This model represents five separate financial ratios; these are represented in the following formula:

$$
\mathrm{Z}=1.042 \mathrm{X} 1+0.42 \mathrm{X} 2+0.461 \mathrm{X} 3+0.463 \mathrm{X} 4+0.271 \times 5
$$

Where: $Z=$ weighted average of five separate ratios

$\mathrm{X} 1=$ net profit after tax $/$ the total assets. This rate measures the overall effectiveness of the company at a profitability through investment.

$\mathrm{X} 2=$ total equity/total liabilities this measure comparing the total equity in the company to the total liabilities.

$\mathrm{X} 3$ = cash assets/ current liabilities. Cash ratios a liquidity indicator of the company by measuring the amount of cash and cash equivalents or money invested in current assets to cover current liabilities

$\mathrm{X} 4=$ Sales / total assets. Measure the efficiency of the company's assets in proportion to the sales.

X5 = cash assets / total assets. compares the dollar amount of highly liquid assets for every one dollar of assets (Shaker et al., 2008).

\subsection{Variables That Used in Testing the Hypotheses}

Operating cash flow ( OCF) It measures the amount of cash generated by operations. Operating cash flow is important because it indicates whether the company was able to generate sufficient positive cash flow to maintain and grow its business. Investing cash flow (ICF) it represents Inflows and out flows of cash flows relating to the purchase and sale of investments shows .Financing cash flow (FCF)Resulting from activities such as increase or reduction the capital and repayment of investors, add or change loans or issuing shares. Size equals the total assets of the company. Equity equals total equity to shareholders.

\subsection{The Data}

Data were collected from Palestine Exchange reports. the study covers the period 2013and 2014estimates annually. And use to analyze the data using Statistical Package for the Social Sciences (Spass). The study sample equal 42 company, includes five sectors: Service Sector, Insurance Sector, Industry Sector, Investment Sector, Banks and financial service. The sample was divided to multiple categories according to(Operating cash flow, Investing cash flow, Financing cash flow Size , Equity ) to test hypotheses.

1. Calculation of the value Kida's $Z$ score of two years and then calculating the average for this ratio.

2. Sort Companies according to the five variables and arranged from low to high.

3. The study sample was divided into two parts so that each groupincludes 21 companies. As shown in the appendix.

\subsection{Hypotheses}

H01: There is no difference in Z-score between Palestinian listed companies that have high operating cash flows and Palestinian listed companies that have low operating cash flows.

H02: There is no difference in Z-score between Palestinian listed companies that have high investing cash flows and Palestinian listed companies that have low investing cash flows.

H03: There is no difference in Z-score between Palestinian listed companies that have high financing cash flows and Palestinian listed companies that have low financing cash flows.

H04: There is no difference in Z-score between Palestinian listed companies that have high total assets and Palestinian listed companies that have low total assets.

H05: There is no difference in Z-score between Palestinian listed companies that have high total equity and Palestinian listed companies that have low total equity.

\subsection{Independent Samples T-Test}

To test the hypotheses including the two groups separate from each other, we need to use the independent samples t-test to find the differences between the averages of two groups independent samples

\section{Results}

\subsection{Descriptive Statistics}

In this part will be displayed descriptive statistics such as mean, median, standard deviation, and the highest and lowest value. In table 1 can be seen that the mean of $Z$ value equal 3.3083 which is considered as a good sign for being successful, and the maximum of $Z$ value equal 29.65, this value for Arab Investors $A R A B$ in the Investment Sector. 
Table 1. Descriptive statistics

\begin{tabular}{llllll}
\hline & $\mathrm{N}$ & Minimum & Maximum & Mean & Std. Deviation \\
\hline Z-score value & 42 & .22 & 29.65 & 3.3083 & 6.27154 \\
Valid N (listwise) & 42 & & & & \\
\hline
\end{tabular}

And the minimum value equal 0.22 this value for Arab Real Estate Establishment ARE in the Service Sector. The following table 2 shows calculated Z-score value for Service Sector. The average Z-score value was calculated for 2013 and 2014.

Table 2. Z-score value for service sector

\begin{tabular}{ll}
\hline Service Sector & Z-score value \\
\hline Al-Wataniah Towers ABRAJ & 7.51 \\
Arab Hotels AHC & 0.65 \\
Arab Real Estate Establishment ARE & 0.22 \\
Arab Palestinian Shopping Centers PLAZA & 1.56 \\
Globalcom Telecommunications GCOM & 0.94 \\
Nablus Surgical Center NSC & 0.74 \\
Pal Aqar Company For Real Estate Development And Management PALAQAI & 0.87 \\
Palestine Telecommunications PALTEL & 1.64 \\
Palestine Electric PEC & 1.45 \\
The Ramallah Summer Resorts RSR & 1.31 \\
Palestinian Company for Distribution \& Logis- WASSEL & 0.52 \\
Wataniya Palestine Mobile Telecommunications WATANIYA & 5.62 \\
The Average of Z - score value & $\mathbf{1 . 9 2}$ \\
\hline
\end{tabular}

The Average of Z-score value for this sector equals 1.92The highest value of Z-score for Al-Wataniah Towers ABRAJ and equal 7.51. Companies that have a Z-score of $>0.38$ are considered as a good sign for being successful .and lowest value for Arab Real Estate Establishment ARE. companies which have a Z-score of $<0.38$ had potential serious problems and may not be able to continue. And According to company's data losses have achievedin2013and 2014.

Table 3. Z-score value for insurance sector

\begin{tabular}{ll}
\hline Insurance Sector & \\
\hline Ahleia Insurance Group AIG & 0.37 \\
Global United Insurance GUI & 0.69 \\
AL-Mashreq Insurance MIC & 0.45 \\
National Insurance NIC & 0.47 \\
Palestine Insurance PICO & 0.29 \\
Al-Takaful Palestinian Insurance TIC & 0.69 \\
Trust International Insurance & 0.67 \\
The Average of Z - score value & $\mathbf{0 . 5 2}$ \\
\hline
\end{tabular}

The Average of Z-score value for this sector equals 0.52. The highest value of Z-score for Global United Insurance GUIAl-Takaful Palestinian Insurance TIC and equal 0.69. companies that have a Z-score of $>0.38$ are considered as a good sign for being successful. while lowest value for Palestine Insurance PICOequal0.29 and Ahleia Insurance Group AIG equal 0.37. companies which have a Z-score of $<0.38$ had potential serious problems and may not be able to continue. 
Table 4. Z-score value for insurance sector

\begin{tabular}{ll}
\hline Industry Sector & \\
\hline Arab Company for Paints Products APC & 1.69 \\
Palestine Poultry AZIZA & 1.54 \\
Beit Jala Pharmaceutical BJP & 1.47 \\
Birzeit Pharmaceuticals BPC & 2.06 \\
Al-Shark Electrode ELECTRODE & 5.86 \\
Golden Wheat Mills GMC & 3.22 \\
Jerusalem Cigarette JCC & 1.05 \\
Jerusalem Pharmaceuticals JPH & 1.23 \\
Palestine Plastic Industries LADAEN & 0.89 \\
National Aluminum \& Profile NAPCO & 0.84 \\
The National Carton Industry NCI & 4.05 \\
Dar Al shifa Pharmaceuticals PHARMACACRE & 0.85 \\
The Vegetable Oil Industries VOIC & 7.58 \\
The Average of Z - score value & $\mathbf{2 . 4 9}$ \\
\hline
\end{tabular}

The Average of Z-score value for this sector equals 2.49. The highest value of Z-score for The Vegetable Oil Industries VOIC equal 7.58. while lowest value for National Aluminum \& Profile NAPCO equal 0.84.

Table 5. Z-score value for investment sector

\begin{tabular}{ll}
\hline Investment Sector & \\
\hline Arab Palestinian Investment APIC & 1.31 \\
Al-Aqariya Trading Investment & 2.31 \\
Arab Investors ARAB & 29.65 \\
Jerusalem Real Estate Investment JREI & 0.53 \\
Palestine Development \& Investment PADICO & 0.88 \\
Palestine Investment \& Development PID & 28.87 \\
Palestine Industrial Investment PIIC & 1.74 \\
Palestine Real Estate Investment PRICO & 0.89 \\
Union Construction and Investment & 9.71 \\
The Average of Z-score value & $\mathbf{8 . 4 3}$ \\
\hline
\end{tabular}

The Average of Z-score value for this sector equals 8.43. This is where the highest value in all sectors. The highest value of Z-score for Arab Investors ARAB equal 29.65.while lowest value for Palestine Real Estate Investment PRICO equal 0.53 .

Table 6. Z - score value for Banks and financial service

\begin{tabular}{ll}
\hline Banks and financial service \\
\hline Palestine Securities Exchange PSE & $\mathbf{4 . 0 7}$ \\
\hline
\end{tabular}

\subsection{Normality Test}

Normality test was conducted using Kolmogorov-Smirnov and Shapiro-Wilk the results in table 7 showed that the data do not follow a normal distribution .so we used non parametric test to test the hypotheses.

Table 7. Tests of Normality

\begin{tabular}{lllllll}
\hline & \multicolumn{5}{l}{ Kolmogorov-Smirnov } \\
\cline { 2 - 6 } & Statistic & Df & Sig. & Shapiro-Wilk \\
\hline$Z-$ score & .325 & 42 & .000 & .469 & 42 & .000 \\
\hline
\end{tabular}

a. Lilliefors Significance Correction 


\subsection{Independent Samples T-Test}

To test the hypotheses independent samples T-test (non parametric) has been used. because It was conducted by using the normality test that data do not follow the normal distribution

The table 8 shows that the value of independent samples Mann-Whitney U Test is not significant of the operating series.

Table 8. The value of independent samples Mann-Whitney U test

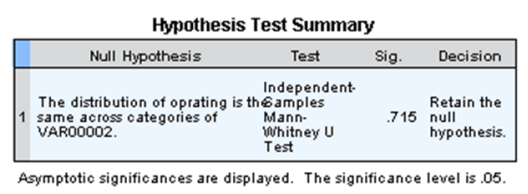

So we accepted the null hypothesis to the effect that there was no statistically significant difference in Z-score between Palestinian listed companies that have high operating cash flows and Palestinian listed companies that have low operating cash flows.

The table 9 shows that the value of independent samples Mann-Whitney U Test is not significant at $5 \%$ of the investing series.

Table 9. The value of independent samples Mann-Whitney U Test

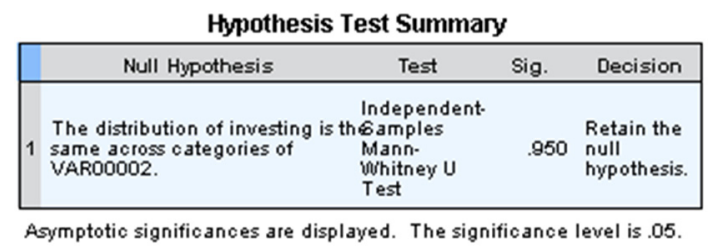

So we accepted the null hypothesis to the effect that there was no statistically significant difference in Z-score between Palestinian listed companies that have high investing cash flows and Palestinian listed companies that have low investing cash flows

The table 10 shows that the value of independent samples Mann-Whitney U Test is not significant of the financing series.

Table 10. The value of independent samples Mann-Whitney U test

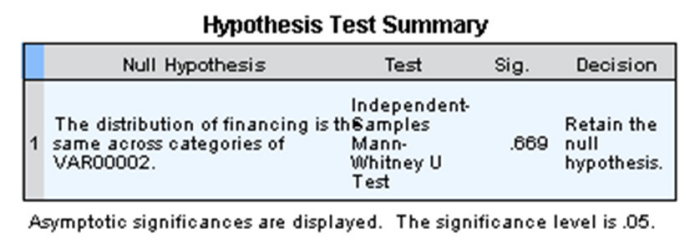

So we accepted the null hypothesis to the effect that there was no statistically significant difference in Z-score between Palestinian listed companies that have high financing cash flows and Palestinian listed companies that have low financing cash flows

The table 11 shows that the value of independent samples Mann-Whitney U Test is not significant of the assets series. 
Table 11. The value of independent samples Mann-Whitney U test

\begin{tabular}{|c|c|c|c|c|}
\hline \multicolumn{5}{|c|}{ Hypothesis Test Summary } \\
\hline & Null Hypothesis & Test & Sig. & Decision \\
\hline 1 & $\begin{array}{l}\text { The distribution of assets is the } \\
\text { same across categories of } \\
\text { VARO00002. }\end{array}$ & $\begin{array}{l}\text { Independent- } \\
\text { Samples } \\
\text { Mann- } \\
\text { Whitney U } \\
\text { Test }\end{array}$ & .064 & $\begin{array}{l}\text { Retain the } \\
\text { null } \\
\text { hypothesis. }\end{array}$ \\
\hline
\end{tabular}

So we accepted the null hypothesis to the effect that there was no statistically significant difference in Z-score between Palestinian listed companies that have high assets cash flows and Palestinian listed companies that have low assets cash flows

The table 12 shows that the value of independent samples Mann-Whitney U Test is not significant of the equity series

Table 12. The value of independent samples Mann-Whitney U test

\begin{tabular}{|c|c|c|c|c|}
\hline \multicolumn{5}{|c|}{ Hypothesis Test Summary } \\
\hline & Null Hypothesis & Test & Sig. & Decision \\
\hline 1 & $\begin{array}{l}\text { The distribution of equity is } \\
\text { same across categories of } \\
\text { VARO0002. }\end{array}$ & $\begin{array}{l}\text { Independent- } \\
\text { hesamples } \\
\text { Mann- } \\
\text { Whitney U } \\
\text { Test }\end{array}$ & .615 & $\begin{array}{l}\text { Retain the } \\
\text { null } \\
\text { hypothesis. }\end{array}$ \\
\hline
\end{tabular}

So we accepted the null hypothesis to the effect that there was no statistically significant difference in Z-score between Palestinian listed companies that have high equity cash flows and Palestinian listed companies that have low equity cash flows.

\section{Conclusion}

Kida's model depends on income statement, the balance sheet. The income statement shows the result of the business during the financial period, and there is no relationship between these profits and the cash available in the company, but it expresses the difference between the net sales and expenses of the company in accordance with the matching principle based on the accrual basis. On this basis, the number of net income shown by the statement of income does not express the real value of the net cash flow, which is acquired by the company during the accounting period, and the financial position which is reflected in the balance sheet of the company at the end of the accounting period is not reflect the cash Position at the end of the period into account the size, whether the size of the assets or property

This is confirmed by the results of the study with regard to the relationship between the cash flow and Kida's model. It has been observed that some of the companies achieved a value higher than 0.38 in the $\mathrm{z}$ score but they have losses in 2013 and 2014. And vice versa companies had achieved less than 0.38 and achieved a profit during the study period.

The results also show that we accept all null hypotheses, so Kida's model does not distinguish between high and low cash flow and the size. This is in line with (Beaver, 1966) it is noted that not all ratios predict failed and non-failed firms with the same degree of success. According to (Alkhatib \& Al Bzour, 2011) this is because companies may not be using such models in their financial and credit analyses.

What distinguishes the study from previous studies is: this study attempts to answer are Palestinian listed companies that have high (operating, investing, financing) cash flows different in Z-score from the companies that have low cash flows? Are Palestinian listed companies that have high assets are different in Z-score from companies that low have assets? Are Palestinian listed companies that have high equity different in Z-score from the companies that low have equity? These goals, according to the researcher's knowledge, have not been discussed before, either by Palestinian researchers or in other countries limitations and problems of the research the failure of some companies to disclose all financial data, as some departments conceal some information or mislead some of them for purposes that serve their interests or satisfy shareholders .In light of the results of the study, it may be appropriate to use the Kida Model in forecasting financial failure, as it has proven successful, as an indicator to predict financial failure. Conducting more research on the Kida model, as it needs to adjust the number of financial ratios used in it. 


\section{Acknowledgements}

The researcher wants to thank Palestine Technical University-Kadoorie for its constant moral and financial support for this research as well as scientific research in general.

\section{References}

Alawi \& Graibh. (2008). Predict Defaults On Companies Using Multi-Directional Measurement: An Empirical Study on the Services Sector in Jorda Studies. Management Science, 35, 377-397.

Al-Hmadani \& Al-Qtan. (2013). Using Model Sherrod to Measure the Financial Failure of a Public Company for the Manufacture of Medicines and Medical Supplies in Nineveh. Journal of Anbar University Economic and Administrative Sciences, 5(10), 449-473. https:/www.iasj.net/iasj/article/76478

Alkhatib \& Al Bzour. (2011). Predicting Corporate Bankruptcy of Jordanian Listed Companies: Using Altman and Kida Models. International Journal of Business and Management, 6(3).

Abu, O. (2014). Empirical Tests on Financial Failure Prediction Models Interdisciplinary. Journal of Contemporary Research in Business, 5(9), 29-43. Retrieved from https://journal-archieves36.webs.com/29-43jan14.pdf

Almansour. (2015). Empirical Model for Predicting Financial Failure. American Journal of Economics, Finance and Management, 1(3), 113-124. Retrieved from https://www.researchgate.net/publication/331166366_Empirical_Model_for_Predicting_Financial_Failure

Al-Sulaiti, \& Omar (2007). Applying Altman Z-Score Model of Bankruptcy on Service Organizations and its implications on marketing concepts and strategies. Journal of International Marketing \& Marketing Research, 32(2), 59-74. Retrieved from https://www.econbiz.de/Record/applying-altman-z-score-model-of-bankruptcy-on-service-organizations-an d-its-implications-on-marketing-concepts-and-strategies-sulaiti-khalid/10003477405

Adrian, B. (2011). Financial crisis causes con text and consequences. Prentice Hall. Retrieved from https://books.google.ps/books/about/Financial_Crisis.html?id=REWYSQAACAAJ\&redir_esc=y

Beaver. (1966). Financial Ratios as Predictors of Failure Empirical Research in Accounting: Selected Studies (pp. 71-111). Retrieved from https://www.jstor.org/stable/2490171?seq=1

Bărbuţă-Mişu, \& Codreanu. (2014). Analysis and Prediction of the Bankruptcy Risk in Romanian Building Sector Companies. Ekonomika, 93, 131-146. Retrieved from https://www.researchgate.net/publication/320269392_Analysis_and_Prediction_of_the_Bankruptcy_Risk_i n_Romanian_Building_Sector_Companies

Brigham \& Gapenski. (1994). Financial management theory and practice (7th ed.). Retrieved from https://www.amazon.com/Study-guide-financial-management-practice/dp/0030980674

Collins. (1972). An Empirical Prediction on Bankruptcy Prediction Models. Financial Management, 9(2), 52-57. Retrieved from https://www.jstor.org/stable/3665168?seq=1

Collins. (1980). An Empirical Comparison of Bankruptcy Prediction Models. Financial Management, 52-57.

Retrieved from https://scholar.google.com/scholar?q=An+Empirical+Comparison+Of+Bankruptcy+Prediction+Models+Fi nancial+Management $\&$ hl $=$ en\&as_sdt $=0 \&$ as_vis $=1 \&$ oi $=$ scholart

Doukas. (1986). Bankers versus bankruptcy prediction models: An empirical investigation, 1979-1982. Applied Economics, $\quad$ 18(5), 479-493.

Retrieved

from https://www.tandfonline.com/doi/abs/10.1080/00036848608537443

Edmister. (1972). An Empirical Test of Financial Ratio Analysis for Small Business Failure Prediction. Journal of Finance, 27(1), 139-140.

Keener. (2013). Predicting The Financial Failure of Retail Companies In The United States. Journal of Business \& Economics Research, 11(8), 373-380. Retrieved from https://core.ac.uk/download/pdf/268112629.pdf

Mears. (1966). Discussion of Financial Ratios as Predictors of Failure. Journal of Accounting Research, 4(3), 119-122.

Mine \& Hakan. (2006). Prediction of corporate financial distress in an emerging market: the case of Turkey. 
Cross Cultural Management: An International Journal, 13(4), 277-295.

Rmo \& Alwatar. (2010). The Development of the Use of Financial Analysis Methods to Predict the Failure of Industrial Public Companies: Study on a sample of industrial Iraqi public companies listed on the Iraq Stock Exchange.

Shirata. (1998). Financial Ratios as Predictors of Bankruptcy in Japan: An Empirical Research. Retrieved from http://www.apira2013.org/past/apira1998/archives/pdfs/31.pdf

Shaheen \& Mate. (2011). A Proposed Model for Predicting Failures of Banking Institutions in Palestine -Empirical Study. Journal of Najah University Research (Humanities), 25(4), 850-878.

Shaker, I. N. (2008). Financial Analysis entrance to the decision-making (2nd ed.).

Shirata. (2011). Extracting Key Phrases as Predictors of Corporate Bankruptcy: Empirical Analysis of Annual Reports by Text Mining. Journal of Emerging Technologies in Accounting, 8, 31-44.

Wilcox. (1971). A Simple Theory of Financial Ratios as Predictors of Failure. Journal of Accounting Research, Autumn, 389-395.

Appendix

\begin{tabular}{|c|c|}
\hline companies that have low operating cash flows & $\mathrm{z}$ \\
\hline-2548710.5 & 0.37 \\
\hline-1322147 & 0.29 \\
\hline-1042503.5 & 1.05 \\
\hline-754397 & 0.47 \\
\hline-665562.5 & 0.52 \\
\hline-398155 & 2.31 \\
\hline-289200.5 & 0.65 \\
\hline-169846 & 0.94 \\
\hline-129440.5 & 0.22 \\
\hline-115754 & 28.87 \\
\hline-110040 & 4.07 \\
\hline-88641.5 & 7.58 \\
\hline-75811 & 0.53 \\
\hline 12060 & 29.65 \\
\hline 87220 & 0.89 \\
\hline 88815.5 & 5.86 \\
\hline 102744 & 1.31 \\
\hline 249342 & 0.87 \\
\hline 294570 & 7.51 \\
\hline 381075 & 0.84 \\
\hline 527970 & 4.05 \\
\hline companies that have high operating cash flows & $\mathrm{z}$ \\
\hline 552722 & 3.22 \\
\hline 666155 & 1.69 \\
\hline 811876 & 1.47 \\
\hline 932944 & 0.74 \\
\hline 1221528 & 1.56 \\
\hline 1387357 & 0.85 \\
\hline 1461041.5 & 0.45 \\
\hline 2091393.5 & 0.69 \\
\hline 2200626 & 9.71 \\
\hline 2289155 & 0.69 \\
\hline 2456794 & 1.23 \\
\hline 2712289.5 & 0.67 \\
\hline 3021481 & 2.06 \\
\hline 3909781.5 & 0.89 \\
\hline 3929940.5 & 1.74 \\
\hline
\end{tabular}




\begin{tabular}{ll}
\hline 4124421.5 & 1.54 \\
4285500 & 0.88 \\
10105736.5 & 1.45 \\
13538653.5 & 1.31 \\
20215040 & 5.62 \\
144054500 & 1.64 \\
\hline
\end{tabular}

\begin{tabular}{|c|c|}
\hline companies that have low investing cash flows & $\mathrm{z}$ \\
\hline-107194000 & 1.64 \\
\hline-18631080.5 & 5.62 \\
\hline-9811666 & 0.89 \\
\hline-9493460.5 & 1.31 \\
\hline-3688760.5 & 0.85 \\
\hline-2372466 & 0.69 \\
\hline-2142116 & 0.67 \\
\hline-2068662 & 2.06 \\
\hline-1945258.5 & 9.71 \\
\hline-1592404 & 0.69 \\
\hline-1174707.5 & 1.56 \\
\hline-1086510 & 1.23 \\
\hline-1002032.5 & 0.45 \\
\hline-848154 & 1.54 \\
\hline-595153.5 & 0.84 \\
\hline-431265 & 1.74 \\
\hline-238519.5 & 1.47 \\
\hline-224900 & 4.05 \\
\hline-145159 & 28.87 \\
\hline-140154 & 0.29 \\
\hline-137176.5 & 0.74 \\
\hline companies that have high investing cash flows & $\mathrm{z}$ \\
\hline-130087.5 & 1.31 \\
\hline-53066 & 1.69 \\
\hline-52303 & 0.89 \\
\hline-39723.5 & 0.65 \\
\hline-34281 & 0.94 \\
\hline-24910 & 29.65 \\
\hline-13093.5 & 5.86 \\
\hline-12475.5 & 0.87 \\
\hline 81410.5 & 0.22 \\
\hline 82612.5 & 7.51 \\
\hline 114395 & 0.52 \\
\hline 159314 & 2.31 \\
\hline 173067 & 0.53 \\
\hline 225969.5 & 4.07 \\
\hline 293085 & 1.05 \\
\hline 386137.5 & 3.22 \\
\hline 411440 & 1.45 \\
\hline 1211347.5 & 0.47 \\
\hline 2160968 & 7.58 \\
\hline 3077585.5 & 0.37 \\
\hline 9598500 & 0.88 \\
\hline companies that have low financing cash flows & $\mathrm{z}$ \\
\hline-43909500 & 1.64 \\
\hline-16974500 & 0.88 \\
\hline
\end{tabular}




\begin{tabular}{|c|c|}
\hline-8852115.5 & 5.62 \\
\hline-7637968.5 & 1.45 \\
\hline-2966463 & 1.74 \\
\hline-2936948 & 1.54 \\
\hline-2067847.5 & 0.47 \\
\hline-1539803 & 7.58 \\
\hline-1125000 & 0.67 \\
\hline-1062113 & 3.22 \\
\hline-583535 & 2.06 \\
\hline-505221 & 0.69 \\
\hline-487500 & 1.69 \\
\hline-468381.5 & 1.05 \\
\hline-404655 & 7.51 \\
\hline-296461.5 & 0.45 \\
\hline-277553 & 1.47 \\
\hline-247393.5 & 4.05 \\
\hline-239483.5 & 1.23 \\
\hline-230147 & 0.53 \\
\hline-165707 & 0.37 \\
\hline companies that have high financing cash flows & $\mathrm{z}$ \\
\hline-139082 & 0.87 \\
\hline-97150 & 5.86 \\
\hline-45714 & 0.89 \\
\hline-15116 & 1.31 \\
\hline-10850.5 & 1.56 \\
\hline-8290.5 & 0.22 \\
\hline-7606 & 0.94 \\
\hline 0 & 2.31 \\
\hline 0 & 29.65 \\
\hline 0 & 0.29 \\
\hline 0 & 28.87 \\
\hline 0 & 4.07 \\
\hline 0 & 9.71 \\
\hline 79445.5 & 0.74 \\
\hline 165218 & 1.31 \\
\hline 268444.5 & 0.84 \\
\hline 329057 & 0.65 \\
\hline 396122 & 0.52 \\
\hline 624785.5 & 0.69 \\
\hline 1729865 & 0.85 \\
\hline 3709249 & 0.89 \\
\hline companies that have low total assets & $\mathrm{z}$ \\
\hline 2660932.5 & 0.22 \\
\hline 2918114.5 & 0.89 \\
\hline 3059255.5 & 28.87 \\
\hline 3092981 & 0.87 \\
\hline 3398008 & 5.86 \\
\hline 4289887 & 1.69 \\
\hline 4633730.5 & 0.94 \\
\hline 4684383 & 2.31 \\
\hline 6450269 & 4.05 \\
\hline 9265181.5 & 29.65 \\
\hline 9702215 & 0.74 \\
\hline 10400972 & 1.47 \\
\hline
\end{tabular}




\begin{tabular}{|c|c|}
\hline 11423726.5 & 4.07 \\
\hline 13124599.5 & 7.51 \\
\hline 13676072.5 & 1.56 \\
\hline 14195435.5 & 1.31 \\
\hline 14893278.5 & 0.53 \\
\hline 17876279.5 & 0.52 \\
\hline 18441010.5 & 3.22 \\
\hline 20106629 & 7.58 \\
\hline 22247482.5 & 0.84 \\
\hline companies that have high total assets & $\mathrm{z}$ \\
\hline 22565080.5 & 0.45 \\
\hline 25593951.5 & 0.69 \\
\hline 31390082 & 0.65 \\
\hline 32468305 & 0.29 \\
\hline 33062237.5 & 1.54 \\
\hline 40432951.5 & 0.69 \\
\hline 41629851 & 1.05 \\
\hline 41826689.5 & 9.71 \\
\hline 44959761 & 0.85 \\
\hline 48375366.5 & 0.37 \\
\hline 48628925 & 1.74 \\
\hline 53435842.5 & 1.23 \\
\hline 67258476 & 2.06 \\
\hline 76956330 & 0.47 \\
\hline 89500458 & 0.67 \\
\hline 110769979.5 & 1.45 \\
\hline 117265700 & 0.89 \\
\hline 244061121.5 & 1.31 \\
\hline 273971152 & 5.62 \\
\hline 708458500 & 1.64 \\
\hline 818542500 & 0.88 \\
\hline companies that have low total equity & $\mathrm{z}$ \\
\hline 623900.5 & 0.22 \\
\hline 1865446.5 & 0.87 \\
\hline 1995709 & 0.89 \\
\hline 2956347.5 & 1.69 \\
\hline 3008666 & 28.87 \\
\hline 3149891.5 & 5.86 \\
\hline 3346083 & 0.94 \\
\hline 3503190.5 & 0.45 \\
\hline 3932970 & 2.31 \\
\hline 4759177.5 & 0.29 \\
\hline 4822299.5 & 0.74 \\
\hline 5692813.5 & 4.05 \\
\hline 5711418 & 0.52 \\
\hline 7284944.5 & 1.47 \\
\hline 8794464.5 & 0.53 \\
\hline 9066553.5 & 29.65 \\
\hline 9174781.5 & 1.56 \\
\hline 10093486.5 & 0.84 \\
\hline 10207275 & 4.07 \\
\hline 10475945.5 & 0.69 \\
\hline 10578504 & 1.31 \\
\hline companies that have high total equity & $\mathrm{z}$ \\
\hline
\end{tabular}




\begin{tabular}{ll}
\hline 10693528.5 & 0.69 \\
12401216 & 7.51 \\
15691903 & 0.37 \\
16094367 & 3.22 \\
18245100 & 0.65 \\
18490269.5 & 1.05 \\
18819765 & 7.58 \\
23339267 & 1.54 \\
24759620 & 0.85 \\
27695579.5 & 0.47 \\
31745412.5 & 0.67 \\
35813789.5 & 1.23 \\
36819701 & 1.74 \\
39875106.5 & 9.71 \\
52589639 & 2.06 \\
78023589.5 & 0.89 \\
78561783.5 & 1.45 \\
83103195.5 & 5.62 \\
98457961.5 & 1.31 \\
512513000 & 1.64 \\
527870000 & 0.88 \\
\hline
\end{tabular}

Explore

\begin{tabular}{|c|c|c|c|c|c|c|}
\hline \multicolumn{7}{|c|}{ Case Processing Summary } \\
\hline & \multicolumn{6}{|l|}{ Cases } \\
\hline & \multicolumn{2}{|l|}{ Valid } & \multicolumn{2}{|l|}{ Missing } & \multicolumn{2}{|l|}{ Total } \\
\hline & $\mathrm{N}$ & Percent & $\mathrm{N}$ & Percent & $\mathrm{N}$ & Percent \\
\hline Oprating & 42 & $93.3 \%$ & 3 & $6.7 \%$ & 45 & $100.0 \%$ \\
\hline
\end{tabular}

\begin{tabular}{|c|c|c|c|c|}
\hline \multicolumn{5}{|c|}{ Descriptives } \\
\hline & & & Statistic & Std. Error \\
\hline \multirow[t]{13}{*}{ Oprating } & Mean & & 3.3083 & .96772 \\
\hline & $95 \%$ Confidence Interval for Mean & Lower Bound & 1.3540 & \\
\hline & & Upper Bound & 5.2627 & \\
\hline & $5 \%$ Trimmed Mean & & 2.0876 & \\
\hline & Median & & 1.2700 & \\
\hline & Variance & & 39.332 & \\
\hline & Std. Deviation & & 6.27154 & \\
\hline & Minimum & & .22 & \\
\hline & Maximum & & 29.65 & \\
\hline & Range & & 29.43 & \\
\hline & Interquartile Range & & 1.85 & \\
\hline & Skewness & & 3.632 & .365 \\
\hline & Kurtosis & & 13.412 & .717 \\
\hline
\end{tabular}

Tests of Normality

Kolmogorov-Smirnov ${ }^{\mathrm{a}}$

Shapiro-Wilk

\begin{tabular}{|c|c|c|c|c|c|}
\hline Statistic & $\mathrm{df}$ & Sig. & Statistic & df & Sig. \\
\hline Oprating .325 & 42 & .000 & .469 & 42 & .000 \\
\hline
\end{tabular}

Oprating

*Nonparametric Tests: Independent Samples. 


\section{NPTESTS}

/INDEPENDENT TEST (oprating) GROUP (VAR00002)

/MISSING SCOPE=ANALYSIS USERMISSING=EXCLUDE

/CRITERIA ALPHA $=0.05$ CILEVEL $=95$

Nonparametric Tests

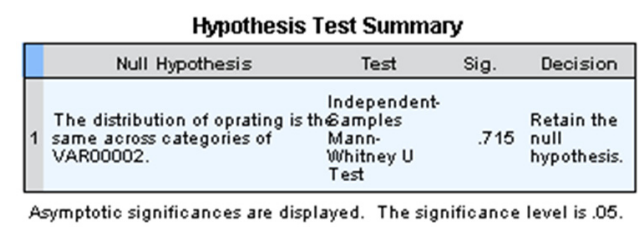

*Nonparametric Tests: Independent Samples.

\section{NPTESTS}

/INDEPENDENT TEST (investing) GROUP (VAR00002)

/MISSING SCOPE=ANALYSIS USERMISSING=EXCLUDE

/CRITERIA ALPHA=0.05 CILEVEL=95.

Nonparametric Tests

Hypothesis Test Summary

\begin{tabular}{|c|c|c|c|c|}
\hline \multicolumn{5}{|c|}{ Hypothesis Test Summary } \\
\hline & Null Hypothesis & Test & Sig. & Decision \\
\hline 1 & $\begin{array}{l}\text { The distribution of investing } \\
\text { same across categories of } \\
\text { VAR00002. }\end{array}$ & $\begin{array}{l}\text { Independent- } \\
\text { is th6amples } \\
\text { Mann. } \\
\text { Whitney U } \\
\text { Test }\end{array}$ & .950 & $\begin{array}{l}\text { Retain the } \\
\text { null } \\
\text { hypothesis. }\end{array}$ \\
\hline
\end{tabular}

*Nonparametric Tests: Independent Samples.

\section{NPTESTS}

/INDEPENDENT TEST (financing) GROUP (VAR00002)

/MISSING SCOPE=ANALYSIS USERMISSING=EXCLUDE

/CRITERIA ALPHA $=0.05$ CILEVEL $=95$.

Nonparametric Tests

Hypothesis Test Summary

\begin{tabular}{|c|c|c|c|c|}
\hline & Null Hypothesis & Test & Sig. & Decision \\
\hline & $\begin{array}{l}\text { The distribution of fin ancing } \\
\text { same across categories of } \\
\text { VARO0002. }\end{array}$ & $\begin{array}{l}\text { Independent- } \\
\text { s thEamples } \\
\text { Mann- } \\
\text { Whitney U } \\
\text { Test }\end{array}$ & .669 & $\begin{array}{l}\text { Retain the } \\
\text { null } \\
\text { hypothesis. }\end{array}$ \\
\hline
\end{tabular}

Asymptotic signific ances are displayed. The signific ance level is 05 .

*Nonparametric Tests: Independent Samples.

NPTESTS

/INDEPENDENT TEST (assets) GROUP (VAR00002)

/MISSING SCOPE=ANALYSIS USERMISSING=EXCLUDE

/CRITERIA ALPHA=0.05 CILEVEL=95.

Nonparametric Tests 


\begin{tabular}{|c|c|c|c|c|}
\hline \multicolumn{5}{|c|}{ Hypothesis Test Summary } \\
\hline & Null Hypothesis & Test & Sig. & Decision \\
\hline 1 & $\begin{array}{l}\text { The distribution of assets is the } \\
\text { same across categaries of } \\
\text { VAR00002. }\end{array}$ & $\begin{array}{l}\text { Independent- } \\
\text { Samples } \\
\text { Mann. } \\
\text { Wuhitney U } \\
\text { Test }\end{array}$ & .064 & $\begin{array}{l}\text { Retain the } \\
\text { null } \\
\text { hypothesis. }\end{array}$ \\
\hline
\end{tabular}

Asymptotic signific ances are displayed. The signific ance level is .05 .

*Nonparametric Tests: Independent Samples.

NPTESTS

/INDEPENDENT TEST (equity) GROUP (VAR00002)

/MISSING SCOPE=ANALYSIS USERMISSING=EXCLUDE

/CRITERIA ALPHA=0.05 CILEVEL $=95$.

Nonparametric Tests

Hypothesis Test Summary

\begin{tabular}{|c|c|c|c|c|}
\hline & Null Hypothesis & Test & Sig. & Decision \\
\hline 1 & $\begin{array}{l}\text { The distribution of equity is } t \\
\text { same across categories of } \\
\text { VAR00002. }\end{array}$ & $\begin{array}{l}\text { Independent- } \\
\text { thesamples } \\
\text { Mann- } \\
\text { Whitney U } \\
\text { Test }\end{array}$ & .615 & $\begin{array}{l}\text { Retain the } \\
\text { null } \\
\text { hypothesis. }\end{array}$ \\
\hline
\end{tabular}

\section{Copyrights}

Copyright for this article is retained by the author(s), with first publication rights granted to the journal.

This is an open-access article distributed under the terms and conditions of the Creative Commons Attribution license (http://creativecommons.org/licenses/by/4.0/). 